\title{
Carboplatin (CBDCA), iproplatin (CHIP), and high dose cisplatin in hypertonic saline evaluated for tubular nephrotoxicity
}

\author{
Marshall P. Goren ${ }^{1}$, Arlene A. Forastiere ${ }^{5}$, Reba K. Wright ${ }^{1}$, Marc E. Horowitz ${ }^{2,4}$, Richard K. Dodge ${ }^{3}$, Barton A. Kamen ${ }^{6}$, \\ Mary J. Viar, and Charles B. Pratt ${ }^{2,4}$ \\ The Department of Pathology and Laboratory Medicine, ${ }^{2}$ Department of Hematology-Oncology, and ${ }^{3}$ Division of Biostatistics, \\ St. Jude Children's Research Hospital, and ${ }^{4}$ Department of Pediatrics, University Tennessee Center Health Sciences, \\ Memphis, Tennessee, USA \\ ${ }^{5}$ The Department of Internal Medicine, Division of Hematology-Oncology, University of Michigan Medical Center, Ann Arbor, \\ Michigan, USA \\ ${ }^{6}$ The Departments of Pediatrics and Pharmacology, University of Texas Health Sciences Center, Dallas, Texas, USA
}

Summary. We compared the acute tubular nephrotoxicity of three platinum compounds in children and adults with solid tumors by monitoring the urinary excretion of alanine aminopeptidase, $N$-acetyl- $\beta$-D-glucosaminidase, and total protein. Cisplatin $\left(100 \mathrm{mg} / \mathrm{m}^{2}\right)$ was administered with mannitol, or at a twofold larger total dosage $\left(50 \mathrm{mg} / \mathrm{m}^{2}\right.$ per day for 4 days) in a $3 \%$ saline infusion. Carboplatin $\left(300 \mathrm{mg} / \mathrm{m}^{2}\right)$ was administered in combination with 5-fluorouracil, and iproplatin was administered in dosages ranging from 216 to $388 \mathrm{mg} / \mathrm{m}^{2}$. Enzymuria and proteinuria induced by cisplatin at a total dosage of $200 \mathrm{mg} / \mathrm{m}^{2}$ on a divided schedule did not significantly differ from that observed for the single $100 \mathrm{mg} / \mathrm{m}^{2}$ dose. Enzymuria and proteinuria induced by carboplatin and iproplatin were significantly less than that for cisplatin; however, one patient developed chronic tubular damage after three courses of carboplatin, and the acute tubular toxicity of iproplatin in one of 15 patients was exceptional. Our findings support the value of administering cisplatin in hypertonic saline on a divided schedule as a strategy to reduce acute tubular damage. Although carboplatin and iproplatin are less nephrotoxic than cisplatin, occasionally patients experience subclinical acute or chronic tubular damage that may lead to overt nephrotoxicity with continued therapy.

\section{Introduction}

Nephrotoxicity is the dose-limiting side-effect of cisplatin [21]. Therapeutic maneuvers to reduce nephrotoxicity include intensive parenteral hydration and mannitol-induced diuresis [14], infusion of cisplatin in a vehicle with a high chloride concentration $[20,24,25]$, or the administration of uroprotective agents [27]. Hydration and diuresis reduce the incidence of clinically significant nephrotoxicity at conventional dosages $\left(100 \mathrm{mg} / \mathrm{m}^{2}\right)$, and the use of $3 \%$ saline has led to the administration of high dosages $\left(200 \mathrm{mg} / \mathrm{m}^{2}\right)$ that have proven clinically useful for several

\footnotetext{
* Supported in part by Biomedical Research Support grant RR05584 (MPG), Cancer Center Support (CORE) grant CA-21765, Childhood Solid Tumor Program Project grant CA23099, American Lebanese Syrian Associated Charities and NCI N01-CM-07405

Offprint requests to: M. P. Goren, Director, Clinical Chemistry, St. Jude Children's Research Hospital, 332 North Lauderdale, P.O. Box 318, Memphis, TN 38101, USA
}

tumor types $[10,24,25]$. Numerous platinum analogues have been synthesized that may be equally effective at dosages that are less nephrotoxic. Carboplatin (cis-diamine (1, 1-cyclobutanedicarboxyatol) platinum, CBDCA, JM8) and iproplatin (cis-dichloro-trans-dihydroxy-bis-isopropylamine platinum IV, CHIP, JM9) are cisplatin analogues that have been found in phase I-II investigational trials to be less nephrotoxic than cisplatin by monitoring serum creatinine and creatinine clearance rates [3, 7]. However, creatinine determination, a reflection of glomerular filtration, is a relatively insensitive measure of druginduced renal tubular damage.

Cisplatin-induced nephrotoxicity can be quantitated by monitoring urinary markers for tubular cell damage $[1,5,8,9,15,17]$. Two widely used markers are urinary alanine aminopeptidase (AAP) and $\mathrm{N}$-acetyl- $\beta$-D-glucosaminidase (NAG), high-molecular-mass enzymes that are localized within the microvilli and lysosomes of renal tubular cells, respectively $[2,18]$. After damage to tubular cells, these enzymes are released into the urine. Cisplatin induces acute enzymuria and proteinuria in a sequence consistent with the development of acute tubular cell necrosis [12]. Total urinary protein concentrations increase because low-molecular-mass serum proteins are less efficiently reabsorbed by dysfunctional tubular cells, and the denuded tubular epithelium exudes protein [4].

We have monitored the relative magnitude of enzymuria and proteinuria associated with administration of cisplatin, carboplatin, and iproplatin. Our primary objectives were to evaluate the two cisplatin analogues for acute tubular nephrotoxicity and to compare the acute tubular damage induced by cisplatin in two clinically useful regimens.

\section{Methods}

Cisplatin, $100 \mathrm{mg} / \mathrm{m}^{2}$, was administered over $6 \mathrm{~h}$ with prehydration consisting of $10 \mathrm{~g} / \mathrm{m}^{2}$ mannitol in $500 \mathrm{ml} / \mathrm{m}^{2} 5 \%$ glucose and $0.22 \%$ saline to children with solid tumors at 3-6 week intervals. These children had serum creatinine concentrations $<1 \mathrm{mg} / \mathrm{dl}$ and had not received other nephrotoxic chemotherapy.

Adults with head and neck cancer received $200 \mathrm{mg} / \mathrm{m}^{2}$ cisplatin $\left(50 \mathrm{mg} / \mathrm{m}^{2}\right.$ per day for 4 days) at 4 -week intervals [10]. Each dose was administered over $30-45 \mathrm{~min}$ in $250 \mathrm{ml} 3 \%$ saline with saline hydration and furosemide diuresis. Urinary chloride concentrations attained during 
each course ranged from 130 to $230 \mathrm{mEq} / 1$, values similar to those reported by Corden et al. [6]. All patients had pretreatment creatinine clearances $>60 \mathrm{ml} / \mathrm{min}$.

Carboplatin, $300 \mathrm{mg} / \mathrm{m}^{2}$, was administered i.-v. over 30 min to seven adults with head and neck cancer [11]. No pretreatment hydration was given. Each dose of carboplatin was followed by a 5-day continuous infusion of 5 -fluorouracil, $1000 \mathrm{mg} / \mathrm{m}^{2}$ per day. All patients had an initial creatinine clearance $>50 \mathrm{ml} / \mathrm{min}$ and had received no prior chemotherapy.

Iproplatin was administered at 3-week intervals to 15 children with solid tumors, in dosages ranging from 216 to $388 \mathrm{mg} / \mathrm{m}^{2}$ [28]. Each dose was administered in $250 \mathrm{ml}$ $0.9 \%$ saline over $2 \mathrm{~h}$. Although all patients had received prior therapy, none had received cisplatin, and all had serum creatinine concentrations $<1.5 \mathrm{mg} / \mathrm{dl}$. Two children had received abdominal radiation after unilateral nephrectomy. Patients were excluded from analysis if they concomitantly received aminoglycosides or amphotericin B.

Urine specimens were obtained before and daily for 1 week after administration of cisplatin, carboplatin, or iproplatin. Urinary concentrations of NAG and AAP were determined by modifications of spectrophotomeric methods $[13,16]$ for automated determinations on a MicroKDA analyzer (American Monitor Corp, Indianapolis,
Ind). Total urinary protein was measured with Coomassie brilliant blue (Bio-Rad Labs, Anaheim, Calif.). Enzyme and protein concentrations were expressed relative to the consentration of urinary creatinine to account for variations in urine output.

For each treatment group, a daily mean concentration was calculated for AAP, NAG, and total protein concentrations for each day beginning on the day before therapy. Also, for each course, the average marker concentrations were calculated for the 7-day period after drug administration. Increases over the pretreatment levels (average marker concentration minus the pretreatment concentration) were used for comparisons of enzyme and protein excretion. Values for courses of $100 \mathrm{mg} / \mathrm{m}^{2}$ cisplatin were compared to those for each of the three other regimens by the Mann-Whitney test (two-sided), with the significance level adjusted by the Bonferonni method [22].

\section{Results}

We studied ten patients receiving their first two doses of cisplatin $\left(100 \mathrm{mg} / \mathrm{m}^{2}\right)$. The daily mean AAP concentration increased briskly after cisplatin administration (Fig. 1) and remained elevated for 1 week. The daily mean NAG concentration increased more slowly than that of AAP,
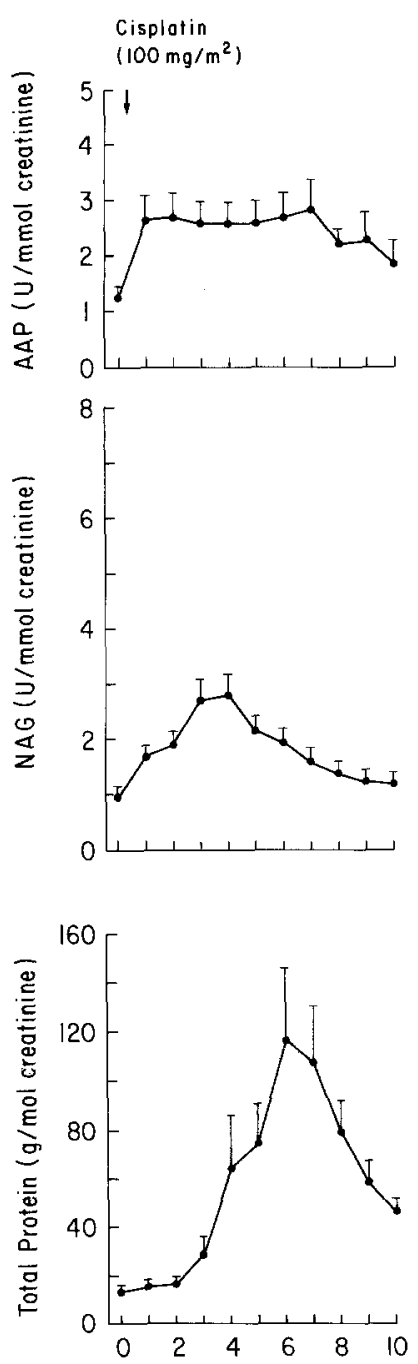

Cisplatin

$\left(50 \mathrm{mg} / \mathrm{m}^{2}\right.$ in $3 \%$ saline $) \quad \begin{aligned} & \text { Corboplatin } \\ & \left(300 \mathrm{mg} / \mathrm{m}^{2}\right)\end{aligned}$
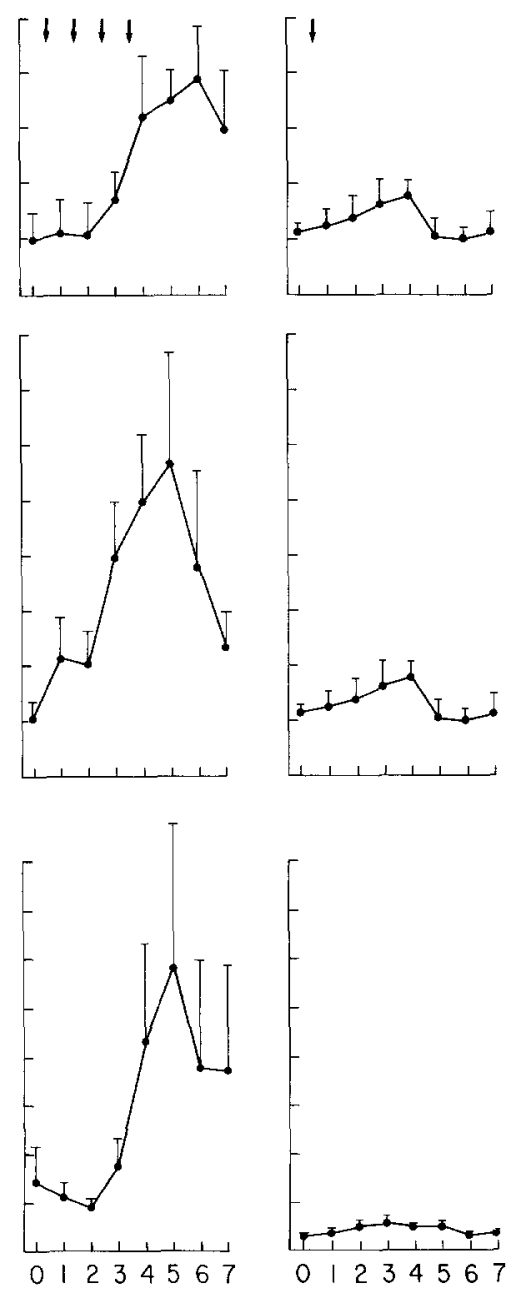

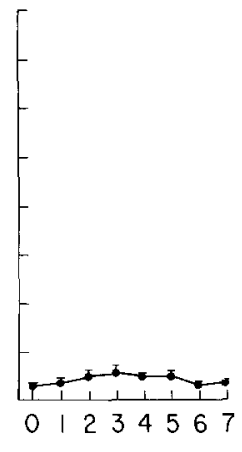

Time (days)
Iproplatin

$\left(216-388 \mathrm{mg} / \mathrm{m}^{2}\right)$
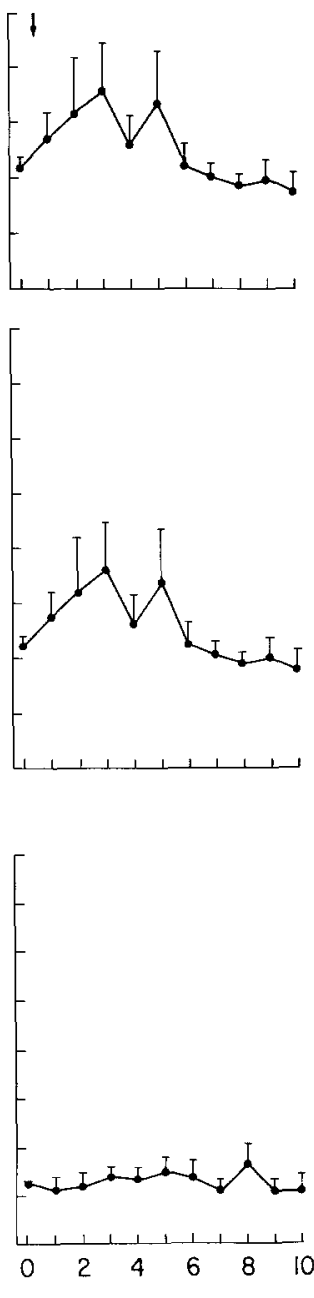

Fig. 1. Daily mean (+SEM) concentrations of urinary alanine aminopeptidase (AAP), $N$-acetyl- $\beta$-D-glucosaminidase (NAG), and total protein before and after 20 courses of cisplatin $\left(100 \mathrm{mg} / \mathrm{m}^{2}\right)$ with mannitol, 5 courses of cisplatin $\left(50 \mathrm{mg} / \mathrm{m}^{2}\right.$ per day for 4 days) in hypertonic saline, 10 courses of carboplatin, and 19 courses of iproplatin. The upper limits of the reference range for $A A P$ and NAG are 3.0 and 1.1 units mmol creatinine, and for total protein, $20 \mathrm{~g} / \mathrm{mol}$ creatinine 
Table 1. Average increases over baseline of urinary enzyme and protein excretion $^{\text {:t }}$

\begin{tabular}{|c|c|c|c|}
\hline DRUG & $\mathrm{NAG}$ & AAP & Total protein \\
\hline & $\begin{array}{l}\text { Units } / \mathrm{mmol} \\
\text { creatinine } \\
\text { Mean }( \pm \mathrm{SD}) n\end{array}$ & $\begin{array}{l}\text { Units } / \mathrm{mmol} \\
\text { creatinine } \\
\text { Mean }( \pm \mathrm{SD}) n\end{array}$ & $\begin{array}{l}\mathrm{g} / \mathrm{mol} \\
\text { creatinine } \\
\text { Mean }( \pm \mathrm{SD}) n\end{array}$ \\
\hline $\begin{array}{l}\text { Cisplatin } \\
\left(100 \mathrm{mg} / \mathrm{m}^{2}\right)\end{array}$ & $1.10 \quad(0.60) 18$ & $1.61 \quad(1.14) 19$ & $59.79 \quad(49.30) 10$ \\
\hline $\begin{array}{l}\text { Cisplatin } \\
\left(200 \mathrm{mg} / \mathrm{m}^{2}\right)\end{array}$ & $\begin{array}{lll}2.39 & (1.59) \quad 5\end{array}$ & $\begin{array}{lll}1.40 & (0.55) \quad 5\end{array}$ & $27.42 \quad(42.43) \quad 5$ \\
\hline Carboplatin & $0.05 *(0.38) 10$ & $0.14 *(0.44) 10$ & $2.70^{*} \quad$ (4.13) 10 \\
\hline Iproplatin & $0.27 *(0.90) 18$ & $0.40^{*}(1.78) 18$ & $2.89 *(17.54) 18$ \\
\hline
\end{tabular}

a Values are the average marker concentrations for the 7-day period after drug administration minus the pretreatment concentration. Tests for differences of these values between cisplatin $\left(100 \mathrm{mg} / \mathrm{m}^{2}\right)$ and each of the three other groups were done by the Mann-Whitney rank sum test (two-sided), with the significance levels adjusted by the Bonferonni method [22]; * $P<0.01$, after adjustment

achieving a peak level by the 4th day after cisplatin administration and then slowly declining towards the predose level. Total urinary protein excretion lagged behind that for NAG, achieving a peak level 1 week after cisplatin treatment. In some instances, AAP and NAG concentrations remained persistently elevated up to administration of the next cisplatin dose. However, urinary protein concentrations returned to pretreatment levels.

We evaluated high-dose cisplatin in three patients receiving their first course of $50 \mathrm{mg} / \mathrm{m}^{2}$ per day for 4 days and one patient receiving his first two courses. Daily mean concentrations of AAP, NAG, and total protein increased in unison (Fig. 1), peaking on the day after the last dose of cisplatin. Increases in AAP, NAG, and total protein excretion over the pretreatment concentration did not significantly differ from those for $100 \mathrm{mg} / \mathrm{m}^{2}$ cisplatin (Table 1 ).

In contrast to cisplatin, carboplatin did not acutely induce enzymuria or proteinuria (Fig. 1). The average marker concentrations did not significantly differ from pre-

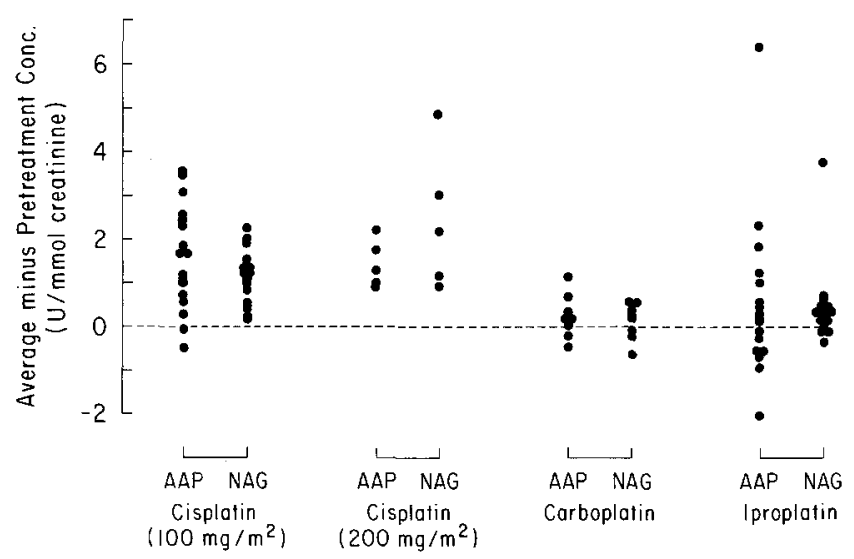

Fig. 2. Comparison of changes in AAP and NAG excretion associated with the four drug regimens. Values shown are the average enzyme concentrations for the 7-day period after drug administration minus the pretreatment concentration. Dashed line indicates no change from pretreatment concentration treatment concentrations (Fig. 2) and were significantly $(\mathrm{P}<0.01)$ lower than those for $100 \mathrm{mg} / \mathrm{m}^{2}$ cisplatin (Table 1).

Enzyme and protein excretion associated with iproplatin was also less than that following cisplatin (Table 1); however, one patient showed a more than threefold increase in average marker excretion over pretreatment concentrations (Fig. 2). This child and several others had high pretreatment enzyme levels, indicating preexisting renal tubular damage that could be ascribed in part to previous therapy or advanced disease. As a result of these increased pretreatment levels, total enzyme, but not protein, excretion was comparable to that for $100 \mathrm{mg} / \mathrm{m}^{2}$ cisplatin (Fig. 1). However, average marker excretion did not significantly differ from pretreatment levels (Fig. 2).

Serum creatinine concentrations, measured at least 3 weeks after therapy, did not significantly differ from pretreatment concentrations for any treatment group.

\section{Discussion}

Our findings demonstrate that $200 \mathrm{mg} / \mathrm{m}^{2}$ cisplatin can be administered over 4 days without a substantial increase in acute nephrotoxicity over that seen for a single $100 \mathrm{mg} / \mathrm{m}^{2}$ dose of cisplatin; this supports the use of hypertonic saline as a strategy to reduce nephrotoxicity. In this study, carboplatin and iproplatin induced negligible acute tubular damage at hematologically toxic dosages. These compounds deserve further investigation to define the spectrum of their therapeutic activity and potential cumulative nephrotoxicity and ototoxicity.

Measurements of urinary markers of nephrotoxicity may be clinically useful to monitor acute $[1,5,8,9,15,17$, 26] and chronic [12] tubular damage. For evaluation of acute nephrotoxicity, interpretation of these measurements depends in part upon the timing of specimen collection. For example, Pendyala et al. [26] reported that NAG excretion after iproplatin administration did not differ from that following cisplatin; however, these investigators obtained urine specimens for no more than $8 \mathrm{~h}$ after cisplatin administration. Figure 1 shows that obtaining specimens at $8 \mathrm{~h}$ is misleading, since NAG levels do not peak until several days after cisplatin administration.

The paucity of acute changes in enzymuria after carboplatin and iproplatin administration does not exclude the possibility of chronic renal damage after multiple courses. The chronic effect of retained intracellular species of platinum compounds may be more important than acute tubular nephrotoxicity [29]. The renal uptake of carboplatin and iproplatin reportedly does not differ substantially from that for cisplatin [19, 23]. Cisplatin induces chronic renal tubular damage in most patients, leading to presistent elevations of urinary NAG [12]. We have studied a patient who developed severe electrolyte abnormalities and a transient decrease in creatinine clearance after three courses of carboplatin. Of interest were chronically elevated urinary enzyme levels before the fourth course of carboplatin at a time when conventional determinations of the creatinine clearance rate and serum creatinine were in an acceptable range for retreatment. Electrolyte wasting and serum creatinine changes also followed the fourth course of carboplatin.

In addition to the total dosage administered, factors that may contribute to acute cisplatin-induced nephrotoxi- 
city include the peak concentration and total duration of exposure to the drug. The increase in urinary AAP concentrations induced by cisplatin on a divided schedule in hypertonic saline was delayed in comparison to the immediate increase observed for the single high-dose cisplatin regimen (Fig. 1). This could reflect delayed sloughing of brush border microvilli, related in part to a protective effect of high urinary chloride concentrations or to lower peak cisplatin concentrations attained with the divided schedule. However, the chloride content of the vehicle for infusion and not the chloruresis itself is reported to ameliorate nephrotoxicity [20]. We are currently evaluating acute tubular nephrotoxicity in relation to the pharmacokinetics of cisplatin administered as a continuous infusion versus intermittent daily bolus.

Acknowledgements. We thank Mindy Lipson PNP and Vicki Kudla RN for clinical assistance, Susan Osborne and Barbara Blair for technical assistance. Specimens from patients receiving CHIP were from individuals who participated in Pediatric Oncology Group Study 8492.

\section{References}

1. Buamah PK, Howell A, Whitby H, Harpur ES, Gescher A (1982) Assessment of renal function during high-dose cis-platinum therapy in patients with ovarian carcinoma. Cancer Chemother Pharmacol 8: 281

2. Burstone MS, Folk JE (1956) Histochemical demonstration of aminopeptidase. J Histochem Cytochem 4: 217

3. Canetta R, Rozencweig M, Carter SK (1985) Carboplatin: the clinical spectrum to date. Cancer Treat Rev 12 (suppl A): 125

4. Carone FA, Ganote CE (1975) D-serine nephrotoxicity. The nature of proteinuria, glucosuria and aminoaciduria in acute tubular necrosis. Arch Pathol 99: 658

5. Cohen AI, Harberg J, Citrin DL (1981) Measurement of urinary $\beta_{2}$-microglobulin in the detection of cisplatin nephrotoxicity. Cancer Treat Rep 65: 1083

6. Corden BJ, Fine RL, Ozols RF, Collins JM (1985) Clinical pharmacology of high-dose cisplatin. Cancer Chemother Pharmacol 14: 38

7. Creaven PJ, Madajewicz S, Pendyala L, Mittelman A, Pontes E, Spaulding M, Arbuck S, Soloman J (1983) Phase I clinical trial of cis-dichloro-trans-dihydroxy-bis-isoporopylamine platinum (IV) (CHIP). Cancer Treat Rep 67: 795

8. Diener U, Knoll E, Langer B, Rautenstrauch H, Ratge D, Wisser H (1981) Urinary excretion of $\mathrm{N}$-acetyl- $\beta$-D-glucosaminidase and alanine aminopeptidase in patients receiving amikacin or cis-platinum. Clin Chim Acta 112: 149

9. Diener U, Knoll E, Ratge D (1982) Urinary excretion of alanine aminopeptidase and $\mathrm{N}$-acetyl- $\beta$-glucosaminidase during sequential combination chemotherapy. J Clin Chem Clin Biochem 20:615

10. Forastiere AA, Wolf GT, Medvec BR, Baker SR (1985) Treatment of head and neck cancer with high dose cisplatin in hypertonic saline. Proc Am Soc Clin Oncol 4: 141 (abstr)

11. Forastiere AA, Natale RB, Vogel WC, Kudla V, Takasugi BJ, Medvec B (1986) Carboplatin and 5-fluorouracil combination chemotherapy in advanced head and neck cancer. (Abstract) Proc Am Soc Clin Oncol 5: 140

12. Goren MP, Wright RK, Horowitz ME (1986a) Cumulative renal tubular damage associated with cisplatin nephrotoxicity. Cancer Chemother Pharmacol 18: 69
13. Goren MP, Wright RK., Osborne S (1986b) Two automated procedures for $N$-acetyl- $\beta$-D-glucosaminidase determination evaluated for detection of drug-induced tubular nephrotoxicity. Clin Chem 32: 2052

14. Hayes DM, Cvitkovic E, Golbey RB, Scheiner E, Helson L, Krakoff IH (1977) High dose cis-platinum diammine dichloride. Amelioration of renal toxicity by mannitol diuresis. Cancer 39: 1372

15. Jones BR, Bhalla RB, Mladek J, Kaleya RN, Gralla RJ, Alcock NW, Reidenberg MM (1980) Comparison of methods of evaluating nephrotoxicity of cis-platinum. Clin Pharmacol Ther 27: 557

16. Jung K, Scholz D (1980) An optimized assay of alanine aminopeptidase activity in urine. Clin Chem 26:1251

17. Kuhn JA, Argy WP, Rakowski TA, Moriarty JK Jr, Shreiner GE, Schein PS (1980) Nephrotoxicity of cis-diammine-dichloro-platinum (II) as measured by urinary $\beta$-glucuronidase. Cancer Treat Rep 64: 1083

18. Le Hir M, Dubach UC, Schmidt U (1979) Quantitative distribution of lysosomal hydrolases in the rat nephron. Histochemistry $63: 245$

19. Lelieveld $P$, van der Vijgh WJF, Veldhuizen RW, Van Velzen D, Van Putten LM, Atassi G, Danguy A (1984) Preclinical studies on toxicity, antitumour activity and pharmacokinetics of cisplatin and three recently developed derivatives. Eur J Cancer Clin Oncol 20: 1087

20. Litterst CL (1981) Alterations in toxicity of cis-dichlorodiammineplatinum-II and in tissue localization of platinum as a function of $\mathrm{NaCl}$ concentration in the vehicle of aministration. Toxicol Appl Pharmacol 61: 99

21. Madias NE, Harrington JT (1978) Platinum nephrotoxicity. Am J Med 65: 307

22. Neter J, Wasserman W (1974) Applied linear statistical models. Richard D. Irvin, Homewood, Ill, p 146

23. Owens SE, Thatcher N, Sharma $H$, Adam N, Harrison R, Smith A, Zaki A, Baer JC, McAuliffe CA, Crowther D, Fox BW (1985) In vivo distribution studies of radioactively labelled platinum complexes; cis-dichlorodiammine platinum (II), cis-trans-dichlorodihydroxy-bis-(isopropylamine) platinum (IV), cis-dichloro-bis-cyclopropylamine platinum (II), and cis-diammine 1, 1-cyclobutanedicarboxylate platinum (II) in patients with malignant disease, using a gamma camera. Cancer Chemother Pharmacol 14: 253

24. Ozols RF, Corden BJ, Jacob J, Wesley MN, Ostchega Y, Young RC (1984) High-dose cisplatin in hypertonic saline. Ann Intern Med 100: 19

25. Ozols RF, Ostchega Y, Myers CE, Young RC (1985) Highdose cisplatin in hypertonic saline in refractory ovarian cancer. J Clin Oncol 3: 1246

26. Pendyala L, Madajewicz S, Shashikant BL, Arbuck SG, Creaven PJ (1985) Evaluation of the nephrotoxicity of iproplatin (CHIP) in comparison to cisplatin by the measurement of urinary enzymes. Cancer Chemother Pharmacol 15: 203

27. Pfeifle CE, Howell SB, Felthouse RD, Woliver TBS, Andrews PA, Markman M, Murphy MP (1985) High-dose cisplatin with sodium thiosulfate protection. J Clin Oncol 3: 237

28. Pratt CB, Kamen BA, Winick N, Sartain P, Champion J, Ragab A (1986) Phase I study of cis-dichloro-trans-dihydroxy- bis (isopropylamine) platinum IV (iproplatin, CHIP) in pediatric patients. Proc Am Soc Clin Oncol 5:205 (abstr)

29. Stewart DJ, Mikhael NZ, Nanji AA, Nair RC, Kacew S, Howard K, Hirte W, Maroun JA (1985) Renal and hepatic concentrations of platinum: relationship to cisplatin time, dose and nephrotoxicity. J Clin Oncol 3: 1251

Received June 19, 1986/Accepted August 5, 1986 